\title{
Effects of dietary supplementation of rumen-protected conjugated linoleic acid to grazing cows in early lactation
}

\author{
S. R. Medeiros, ${ }^{*}$ D. E. Oliveira, † L. J. M. Aroeira, $\ddagger$ M. A. McGuire,§ D. E. Bauman,\# and D. P. D. Lanna $\|^{1}$ \\ *Embrapa Beef Cattle, Campo Grande, Mato Grosso do Sul, 79002-970, Brazil \\ †Department of Animal Science, Santa Catarina State University, Chapecó, Santa Catarina, 89801-070, Brazil \\ †Embrapa Dairy Cattle, Juiz de Fora, Minas Gerais, 36038-300, Brazil \\ $\S$ Department of Animal and Veterinary Science, University of Idaho, Moscow 83844-2330 \\ \#Department of Animal Science, Cornell University, Ithaca, NY 14853-0281 \\ ||Department of Animal Science, University of São Paulo-Escola Superior de Agricultura Luiz de Queiroz, Piracicaba, São Paulo, \\ 13418-900, Brazil
}

\section{ABSTRACT}

Conjugated linoleic acids (CLA) are potent anticarcinogens in animal and in vitro models as well as inhibitors of fatty acid synthesis in mammary gland, liver, and adipose tissue. Our objective was to evaluate long-term CLA supplementation of lactating dairy cows in tropical pasture on milk production and composition and residual effects posttreatment. Thirty crossbred cows grazing stargrass (Cynodon nlemfuensis Vanderyst var. nlemfüensis) were blocked by parity and received $150 \mathrm{~g} / \mathrm{d}$ of a dietary fat supplement of either Ca-salts of palm oil fatty acids (control) or a mixture of Casalts of CLA (CLA treatment). Supplements of fatty acids were mixed with $4 \mathrm{~kg} / \mathrm{d}$ of concentrate. Grazing plus supplements were estimated to provide $115 \%$ of the estimated metabolizable protein requirements from 28 to $84 \mathrm{~d}$ in milk (treatment period). The CLA supplement provided $15 \mathrm{~g} / \mathrm{d}$ of cis-9,trans-11 and $22 \mathrm{~g}$ of cis-10,trans-12. Residual effects were evaluated from 85 to $112 \mathrm{~d}$ in milk (residual period) when cows were fed an $18 \%$ crude protein concentrate without added fat. The CLA treatment increased milk production but reduced milk fat concentration from 2.90 to $2.14 \%$ and fat production from 437 to $348 \mathrm{~g} / \mathrm{d}$. Milk protein concentration increased by $11.5 \%$ (2.79 to $3.11 \%)$ and production by $19 \%$ (422 to $504 \mathrm{~g} / \mathrm{d}$ ) in the cows fed CLA. The CLA treatment decreased milk energy concentration and increased milk volume, resulting in unchanged energy output. Milk production and protein concentration and production were also greater during the residual period for the CLA-treated cows. The CLA treatment reduced production of fatty acids (FA) of all chain lengths, but the larger effect was on short-chain FA, causing a shift toward a greater content of longer chain FA. The CLA treatment increased total milk CLA

Received August 14, 2009.

Accepted November 9, 2009.

${ }^{1}$ Corresponding author: dplanna@esalq.usp.br content by $30 \%$ and content of the trans-10, cis- 12 CLA isomer by $88 \%$. The CLA treatment tended to decrease the number of days open, suggesting a possible effect on reproduction. Under tropical grazing conditions, in a nutritionally challenging environment, CLA-treated cows decreased milk fat content and secreted the same amount of milk energy by increasing milk volume and milk protein production.

Key words: composition, fatty acid, milk, tropical pasture

\section{INTRODUCTION}

The use of conjugated linoleic acids (CLA) as a supplement to dairy cows was initially conceived to increase its content in milk for the benefit of consumer health. The findings of Loor and Herbein (1998) and Chouinard et al. (1999) with abomasal infusion demonstrated that CLA supplements reduced milk fat yield. Subsequent work by Baumgard et al. (2000) demonstrated that the isomer involved in that effect was the trans-10, cis-12 isomer. These results suggested a great potential for the use of CLA as a tool to manipulate milk composition. The availability of mixtures of CLA isomers containing mainly cis-9,trans-11 and trans10, cis-12 allowed the beginning of supplementation trials (Giesy et al., 2002; Bernal-Santos et al., 2003; Perfield et al., 2002). Those studies were done with high-producing cows and demonstrated decreased milk fat content but variable results regarding milk and protein yield. The high-producing cow is challenged to meet its nutritional requirements; thus, inhibition of fat secretion may have favored, in some studies (Mackle et al., 2003; De Veth et al., 2006; Kay et al., 2007), positive responses in milk and milk protein production. A similar situation may occur with dairy cows on tropical pastures, where several nutritional and climatic challenges may constrain milk production. Constraints such as availability and quality of forage, high temperatures and humidity, and greater maintenance requirement of 
Table 1. Composition of supplement ${ }^{1}$ offered to grazing cows from 28 to 84 DIM

\begin{tabular}{|c|c|c|}
\hline Ingredient & $\mathrm{kg} / \mathrm{d}$ & $\%, \mathrm{DM}$ \\
\hline Corn, ground grain & 2.35 & 58.5 \\
\hline Fishmeal & 1.00 & 25 \\
\hline Wheat middlings & 0.23 & 5.5 \\
\hline Soybean meal & 0.22 & 5.5 \\
\hline Premix $^{2}$ & 0.20 & 5.5 \\
\hline Total & 4.00 & 100.0 \\
\hline
\end{tabular}

${ }^{1}$ Fatty acid composition of the supplement ( $\mathrm{g} / 100 \mathrm{~g}$ of fat): palmitic acid: 22.74; stearic acid: 6.50; oleic acid: 27.45; linoleic acid: 33.92 ; linolenic acid: 1.35 .

${ }^{2}$ Contained per kilogram: Ca, 187.5 g; P, 97.5 g; Mg, 22.5 g; S, 75 g; $\mathrm{Na}, 135 \mathrm{~g} ; \mathrm{Cu}, 1,200 \mathrm{mg} ; \mathrm{Fe}, 1,500 \mathrm{mg}$; Mn, 1,500 mg; Zn, 2,250 mg; Co, $45 \mathrm{mg}$; I, $90 \mathrm{mg}$; Se, $38 \mathrm{mg}$; vitamin A, 100,000 IU; vitamin D, 30,000 IU; vitamin E, 500 IU.

cows because of physical activity can hinder the ability to achieve milk production potential. The ability to control the energetic density of milk could be used to reach greater milk volume production. The objective of this work was to determine the effects of CLA supplementation on milk production, milk composition, and fatty acid profile of cows grazing tropical forages.

\section{MATERIALS AND METHODS}

\section{Animals, Management, and Treatments}

The experiment was conducted with cows grazing stargrass (Cynodon nlemfuensis Vanderyst var. nlemfüensis) at Santa Monica Experimental Station $\left(43^{\circ} 42^{\prime} \mathrm{W} ; 22^{\circ} 21^{\prime} \mathrm{S}\right.$; altitude, $364 \mathrm{~m}$ above sea level) at Embrapa Dairy Cattle, Valença, Rio de Janeiro, Brazil. The cows were on a rotational grazing system consisting of 14 paddocks ( 0.5 ha/each). The grazing period was $2 \mathrm{~d}$ per paddock and the grazing cycle was $28 \mathrm{~d}$. The pasture was sampled by simulated grazing and the mean nutritive value on a DM basis was $\mathrm{CP}, 13.3 \%$; ether extract, $1.2 \%$; NDF, $61.4 \%$; sulfuric acid lignin, $3.2 \%$; and ash, $9.1 \%$.

Thirty crossbred Holstein $\times$ Zebu cows in early lactation received a dietary fat supplement of either Ca-salts of palm oil fatty acids (Megalac, Dwight \& Church Co. Inc., Princeton, NJ; control treatment) or a mixture of Ca-salts of CLA (CLA treatment). The concentrate was formulated (Table 1) to supplement the estimated ingested pasture so that the diet would provide $115 \%$ of the estimated MP requirements (NRC, 2001). To formulate the supplements, the predicted DMI was 13.3 $\mathrm{kg}$ of $\mathrm{DM} / \mathrm{d}$ with pasture intake at $9.7 \mathrm{~kg}$ of $\mathrm{DM} / \mathrm{d}$. Concentrate was supplemented to exceed the requirements for vitamins, macro-, and microelements (NRC, 2001). Concentrates were offered twice daily after each milking in individual recipients with the cows restrained
Table 2. Nutritional analysis from pasture and of the supplements during the treatment period (28 to 84 DIM) and residual period ( 85 to 112 DIM) $)^{1}$

\begin{tabular}{lccc}
\hline Chemical analysis & Pasture & $\begin{array}{c}\text { Treatment } \\
\text { period }\end{array}$ & $\begin{array}{c}\text { Residual } \\
\text { period }\end{array}$ \\
\hline $\mathrm{DM}, \%$ & 30.9 & 89.6 & 88.2 \\
$\mathrm{CP}, \%$ of DM & 13.3 & 24.1 & 17.9 \\
Ether extract, \% of DM & 1.7 & 2.9 & 2.6 \\
Ash, \% of DM & 9.1 & 14.4 & 14.1 \\
$\mathrm{NE}_{\mathrm{L}}$, Mcal/kg of DM & 1.29 & 1.95 & 1.60 \\
\hline
\end{tabular}

${ }^{1}$ Cows received $150 \mathrm{~g} / \mathrm{d}$ of dietary fat supplement (top-dressed) consisting of Ca-salts of palm oil fatty acids (control treatment) or Casalts of CLA-60 (Natural Lipids Ltd., Hovdebygda, Norway).

in tie stalls until the supplements were completely consumed.

Cows were blocked by previous milk production and parity into 2 treatment groups. From 28 to 84 DIM they received supplements of either $150 \mathrm{~g}$ of Ca-salts of palm oil (control) or $150 \mathrm{~g}$ of Ca-salts of CLA.

In the CLA supplement, $65 \%$ of the lipid used in the Ca-salt formation (Church \& Dwight Co. Inc.) was a preparation containing CLA isomers (CLA-60, Natural Lipids Ltd., Hovdebygda, Norway), and the balance of fatty acids were from palm oil. The profile of CLA isomers in CLA-60 was $24 \%$ cis-9,trans- 11 , $35 \%$ trans10,cis- $12,15 \%$ trans- 8 , cis- $10,17 \%$ cis-11,trans- 13 , and $9 \%$ other. Therefore, approximately $63 \mathrm{~g}$ of CLA-60 or $22 \mathrm{~g}$ of trans-10,cis-12 was fed daily considering that the calcium salts of CLA protected for this experiment had $70 \%$ as fatty acids, once $30 \%$ were measured as ash.

The residual effect of CLA was also evaluated once the supplementation of Ca-salts was discontinued at 84 DIM and the concentrate was replaced by a commercial concentrate based on wheat middlings from 85 to 112 DIM. The period from 28 to 84 DIM was considered the treatment period and that from 85 to 112 DIM the residual period. The chemical composition of concentrates from both periods is presented in Table 2 .

\section{Milk Production and Composition}

Cows were milked twice daily (0600 and $1400 \mathrm{~h}$ ), and yields were recorded at each milking from 28 to 114 DIM. Milk samples were collected $3 \mathrm{~d}$ a week (Monday, Thursday, and Saturday) from each milking and pooled by day of collection proportionally to yield. Samples were stored at $4^{\circ} \mathrm{C}$ with a preservative (bromopol tablet; D\&F Control System, San Ramon, CA) until analyzed for fat, total protein, lactose, and total solids using infrared analysis (AOAC, 2000; method no. 972.160) with the analytical and calibration methods described by Bernal-Santos et al. (2003). Additional milk samples 
were taken weekly (Friday) from each cow to evaluate MUN. Milk was also sampled for 5 consecutive days from 42 to 47 DIM (period 1) and from 70 to 74 DIM (period 2) within the treatment period, and another similar collection period in the middle of the residual period from 92 to $97 \mathrm{DIM}$ and stored at $-20^{\circ} \mathrm{C}$ without preservative until analyzed for fatty acids.

Blood was collected weekly via venipuncture from the coccygeal vessels following the afternoon milking and before providing the concentrate. Coagulation was prevented by EDTA; plasma was harvested following centrifugation $(2,800 \times g, 15 \mathrm{~min})$ and stored at $-20^{\circ} \mathrm{C}$ until analysis for blood metabolites.

Body weights were determined weekly as the mean of 3 consecutive days, and BCS was determined weekly throughout the study as the average of scores given by 2 individuals. Cows were body scored on a 9-point system (NRC, 1996).

\section{Fatty Acid Analysis}

Milk fat (400 mg) was obtained after milk centrifugation $\left(17,800 \times g, 30 \mathrm{~min}\right.$ at $\left.8^{\circ} \mathrm{C}\right)$. Lipid extraction was performed according to Hara and Radin (1978), and methylation was performed using a methanolic solution of sodium methoxide, as described by Christie (1982), with modifications by Chouinard et al. (1999). The fatty acid composition was determined by gas chromatography with a fused silica capillary column (SP-2560, $100 \mathrm{~m} \times 0.25 \mathrm{~mm} \times 0.2 \mu \mathrm{m}$; Supelco, Bellefonte, PA) and a flame-ionization detector. A gradient temperature program was used, and total time for each run was 70 min. Injector temperature was $250^{\circ} \mathrm{C}$ and detector temperature was $300^{\circ} \mathrm{C}$; injection was via split mode (21:1). Carrier gas was helium $(40 \mathrm{~mL} / \mathrm{min}$ and 124 $\mathrm{kPa}$ on the column head). The CRM-164 (Commission of the European Communities, Community Bureau of Reference, Brussels, Belgium) was used as the standard to establish correction factors for each of the certified fatty acids, converting the percentage of area to weight (mg/g of total fatty acids).

\section{MUN and Plasma Metabolite Analysis}

Milk urea nitrogen analysis was done by an enzymatic method (Ureia Enz-Color, Laborclin, Curitiba, Parana, Brazil). A pooled sample was used as a control to inter-batch variability.

Plasma was analyzed for NEFA, triglyceride (TG), total cholesterol, and glucose. Concentrations of NEFA were determined using a colorimetric-enzymatic method (NEFA C, Wako Pure Chemical Industries, Osaka, Japan) and all samples were analyzed ( $\mathrm{n}=$ 360). Concentrations of TG and glucose were analyzed for plasma samples on DIM 28, 42, 56, and 70 in the treatment period and all $4 \mathrm{wk}$ of the residual period. Cholesterol was assessed for plasma on samples similar to those used for TG and glucose in the treatment period, and at 91 and 105 DIM in the residual period using a colorimetric-enzymatic method (Colesterol Enz-Color, Biodiagnostica, Curitiba, Parana, Brazil). Glucose determination was done by direct reading (glucose oxidase enzyme immobilized in membrane) on an YSI 2700 Select autoanalyzer (Biochemistry Analyzer, Yellow Springs, $\mathrm{OH}$ ). Triglycerides were analyzed by an enzymatic method (TG Enz-Color, Biodiagnostica)

\section{Statistical Analysis}

For milk production, milk composition, BW, BCS, and metabolic parameters (MUN, NEFA, TG, cholesterol, and glucose), analyses were performed using the MIXED procedure of SAS (SAS Institute, 2000) for the treatment period and the residual period. The model included fixed effects of block, treatment, week, and treatment by week interaction, and a random effect of cow.

Fatty acid data were analyzed as a split-plot design through the GLM procedure of SAS (SAS Institute, 2000). The persistence of lactation was compared through the confidence interval test from the difference of the slope coefficient of the regressions as suggested by Neter et al. (1996). Standard error of the means are reported, and differences were considered significant when $P<0.05$ unless otherwise stated.

\section{RESULTS AND DISCUSSION}

\section{Milk Production and Composition}

Cows supplemented with CLA had greater milk yield compared with control animals $(P=0.06)$ during the treatment period (Tables 3 and 4 ). There was no treatment by time interaction for milk yield. Milk fat concentration was depressed $(\sim 26 \%)$ in the treatment period (Tables 3 and 4) because of CLA supplementation $(P<0.0001)$. This effect was observed within 1 wk of treatment (Figure 1), when cows were about 30 DIM, and lasted until wk 1 of the residual period. The reduction in milk fat yield and concentration are in accordance with studies using pure CLA isomers, which demonstrated that the trans-10,cis-12 isomer reduced milk fat synthesis (Baumgard et al., 2000). Other CLA isomers, notably trans-9,cis-11 and cis-10,trans-12, have been associated with this effect (Harvatine et al., 2009).

The reduction in milk fat concentration was observed within $1 \mathrm{wk}$ of treatment (Figure 2) when cows were 
Table 3. Milk yield and composition, BW, and BCS of cows receiving rumen-protected fat supplements in the treatment period

\begin{tabular}{lcccccc}
\hline & \multicolumn{2}{c}{ Treatment $^{1}$} & & & \\
\cline { 2 - 3 } Variable & Control & CLA & & SEM & Treatment & $\begin{array}{c}\text { Time } \times \\
\text { treatment }\end{array}$ \\
\hline Milk yield, kg/d & 15.2 & 16.3 & 0.16 & 0.056 & 0.861 \\
Milk fat, \% & 2.90 & 2.14 & 0.037 & $<0.0001$ & $<0.0001$ \\
Milk fat yield, g/d & 437 & 348 & & 6.1 & 0.002 & 0.010 \\
Milk protein, \% & 2.79 & 3.11 & & 0.018 & 0.001 & 0.005 \\
Milk protein yield, g/d & 422 & 504 & & 5.1 & 0.001 & 0.353 \\
Milk lactose, \% & 4.56 & 4.46 & 0.017 & 0.196 & $<0.0001$ \\
Milk lactose yield, g/d & 692 & 726 & & 7.8 & 0.277 & 0.849 \\
Milk total solids, \% & 10.98 & 10.56 & 0.05 & 0.058 & 0.045 \\
Milk total solids yield, g/d & 1.662 & 1.716 & 17.4 & 0.494 & 0.799 \\
Milk energy output, MJ/d & 37.8 & 36.9 & & 1.12 & 0.613 & 0.391 \\
Milk energy concentration, MJ/kg & 2.500 & 2.270 & 0.015 & 0.0004 & $<0.0001$ \\
BW ${ }^{2}$ kg & 439 & 451 & & 8.6 & 0.498 & 0.548 \\
BCS ${ }^{3}$ & 3.7 & 3.9 & 0.12 & 0.417 & 0.204 \\
\hline
\end{tabular}

${ }^{1}$ Cows $(n=15)$ received a dietary fat supplement consisting of Ca-salts of palm oil fatty acids (control) or Casalts of a mixture of conjugated linoleic acid isomers from 28 to 84 DIM (CLA).

${ }^{2}$ Cows were weighed $3 \mathrm{~d} /$ wk throughout the study.

${ }^{3}$ Cows were scored (9-point scale) by 2 individuals $1 \mathrm{~d} /$ wk throughout the study, and average values were used.

about 30 DIM. Other studies show that the response to CLA inducing milk fat depression (MFD) occurred after several weeks of lactation, which was attributed to a possible attenuation of the cellular signaling to CLA trans-10,cis-12 at the onset of lactation (Bernal-Santos et al., 2003; Castañeda-Gutiérrez et al., 2005). In accordance with that, Moore et al. (2004) worked with periparturient cows ( -10 to $21 \mathrm{~d}$ relative to calving) and observed that a higher CLA dose was required to reduce milk fat in early lactation. A greater relative importance of de novo fat synthesis (i.e., from acetate) in the mammary gland for the low-producing cows of the present experiment, compared with high-producing cows in early lactation, may also explain the lower doses of CLA necessary to reduce milk fat content.

Milk fat yield was diminished by $20 \%$ in the treatment period for cows fed CLA. The intensity of MFD was similar to that obtained by Chouinard et al. (1999) when infusing $28 \mathrm{~g} / \mathrm{d}$ of CLA-60 in the abomasum, but a simple comparison might be inadequate to estimate

Table 4. Milk yield and composition, BW, and BCS of cows from 85 to 112 DIM (residual period ${ }^{1}$ ) after receiving rumen-protected fat supplements from 28 to 84 DIM (treatment period)

\begin{tabular}{|c|c|c|c|c|c|}
\hline \multirow[b]{2}{*}{ Variable } & \multicolumn{2}{|c|}{ Treatment $^{2}$} & \multirow[b]{2}{*}{ SEM } & \multirow[b]{2}{*}{ Treatment } & \multirow{2}{*}{$\begin{array}{l}\text { Time } \times \\
\text { treatment }\end{array}$} \\
\hline & Control & CLA & & & \\
\hline Milk yield, $\mathrm{kg} / \mathrm{d}$ & 11.8 & 13.1 & 0.19 & 0.017 & 0.720 \\
\hline Milk fat, $\%$ & 3.29 & 3.17 & 0.06 & 0.268 & 0.007 \\
\hline Milk fat yield, $\mathrm{g} / \mathrm{d}$ & 387 & 411 & 8.0 & 0.311 & 0.001 \\
\hline Milk protein, $\%$ & 2.84 & 3.05 & 0.02 & 0.017 & 0.001 \\
\hline Milk protein yield, $\mathrm{g} / \mathrm{d}$ & 335 & 398 & 6.3 & 0.006 & 0.266 \\
\hline Milk lactose, \% & 4.44 & 4.39 & 0.03 & 0.563 & 0.002 \\
\hline Milk lactose yield, g/d & 526 & 574 & 9.4 & 0.082 & 0.395 \\
\hline Milk total solids, $\%$ & 11.26 & 11.42 & 0.08 & 0.552 & 0.015 \\
\hline Milk total solids yield, $\mathrm{g} / \mathrm{d}$ & 1.605 & 1.759 & 33.6 & 0.070 & 0.378 \\
\hline Milk energy output, MJ/d & 31.2 & 34.3 & 0.54 & 0.088 & 0.041 \\
\hline Milk energy concentration, $\mathrm{MJ} / \mathrm{kg}$ & 2.643 & 2.634 & 0.03 & 0.899 & 0.029 \\
\hline $\mathrm{BW},{ }^{3} \mathrm{~kg}$ & 440 & 457 & 9 & 0.372 & 0.972 \\
\hline $\mathrm{BCS}^{4}$ & 3.7 & 3.9 & 0.1116 & 0.160 & 0.826 \\
\hline
\end{tabular}

${ }^{1}$ Cows $(\mathrm{n}=15)$ received a dietary commercial diet.

${ }^{2}$ During the treatment period, cows $(\mathrm{n}=15)$ received a dietary fat supplement consisting of Ca-salts of palm oil fatty acids (control) or Ca-salts of a mixture of conjugated linoleic acid isomers from 28 to 84 DIM (CLA).

${ }^{3}$ Cows were weighed $3 \mathrm{~d} /$ wk throughout the study.

${ }^{4}$ Cows were scored (9-point scale) by 2 individuals $1 \mathrm{~d} /$ wk throughout the study, and average values were used. 


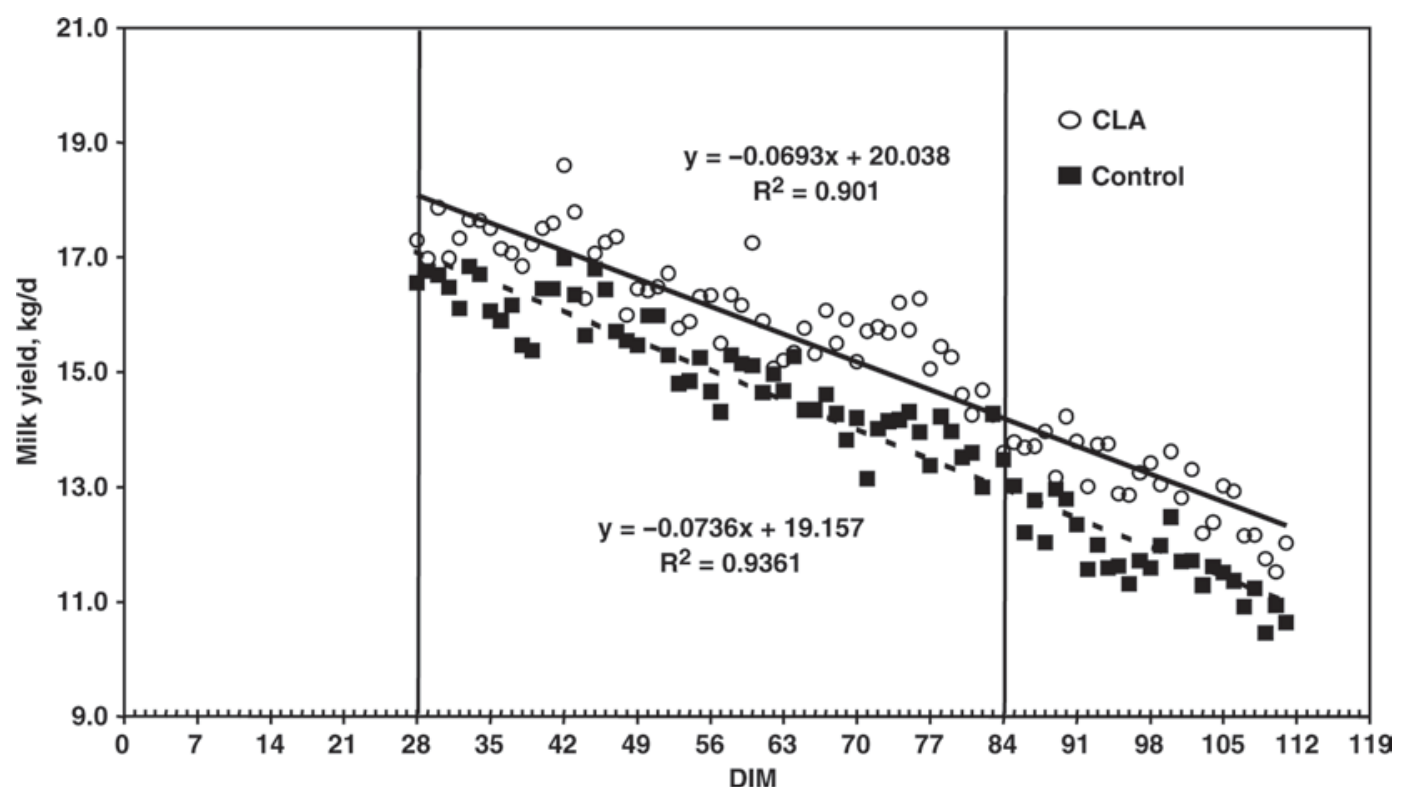

Figure 1. Dispersion of data and regressions of milk yield $(\mathrm{kg} / \mathrm{d})$ for cows fed a rumen-protected fat supplement with (CLA, O) or without conjugated linoleic acid (control, $\mathbf{\square})$ from 28 to 84 DIM (treatment period) and a low-fat supplement without CLA from 85 to 112 DIM (residual period).

the amount of CLA reaching the abomasum of the grazing cows in this work, as control cows already had milk fat content lower than usual for grazing cows of similar genetics; therefore, less CLA may be necessary to achieve the same effect. An explanation for the depressed milk fat observed in the control cows could be the inclusion of fishmeal in the concentrate. The 60 to $70 \mathrm{~g}$ of fishmeal oil present in the diet would be enough to inhibit milk fat synthesis (Chilliard et al., 2001; Gama et al., 2008).

Milk protein content for CLA-treated cows was about $11 \%$ greater $(P=0.001)$ in the treatment period. The greater protein content with the greater milk yield in the CLA-fed cows resulted in increased (19.4\%) milk protein production compared with controls $(P=0.002)$. The increase in milk protein production could be the result of the relatively higher MP of the diet, which may have provided the amino acids demanded by the CLA-treated cows. It could also be hypothesized that protein synthesis was depressed by an energy deficit in the control cows and that reduction in milk fat energy secretion allowed spared energy to be used for protein synthesis in the mammary gland. As pointed out by Perfield et al. (2002), there are several studies in which CLA was supplemented to cows in established lactations without any change in milk yield or milk protein content. This supports the idea that for those changes to occur, animals may need to be in negative energy balance. Mackle et al. (2003) infused a CLA mixture containing almost $60 \%$ of CLA isomers in increasing amounts and, although milk protein content was unchanged, protein production tended to increase at the $40 \mathrm{~g} / \mathrm{d}$ dose. It can also be hypothesized that the better amino acid profile of the fishmeal could have helped in the achievement of the greater milk content and yield in our experiment.

There was no treatment effect for lactose. The greater osmotic effect because of the greater protein content of CLA milk and the high stability of milk osmolality (Jenness, 1985) could have had an effect on lactose, but no difference was observed, in accordance with the usually observed constancy of lactose content (Sutton, 1989; Kennelly, 1996). The large MFD resulted in greater total solids content for the control treatment $(P=0.058)$, but the difference was small because of the greater protein content of the CLA-treated animals that partly compensated for the lower fat production.

Milk energy density (Tables 3 and 4) was altered by treatment, and CLA-treated cows produced less energydense milk $(P<0.001)$. The total amount of energy secreted as milk was unchanged by CLA supplementation. There was also no difference in total DMI for the treatments, as determined by n-alkane technique in an accompanying experiment (Oliveira, 2003): 15.5 vs. $15.0 \mathrm{~kg} / \mathrm{d}$ for control and CLA treatments, respectively $(P=0.4588)$. The average metabolizable energy of the forage was estimated at $2.0 \mathrm{Mcal} / \mathrm{kg}$ of DM (Oliveira, 2003). Therefore, in response to less energy-dense milk from the CLA-treated cows, there was clearly an appropriate increase in milk volume to reach the total 
milk energy output potential of that pasture system of production, around 37 to $38 \mathrm{MJ} / \mathrm{d}$ (Table 3 ).

In the residual period, cows that were fed CLA during the treatment period produced $11 \%$ more milk than those that received Megalac (control treatment). The CLA-treated cows were able to maintain greater milk production even with poorer nutrient availability, because the residual period occurred in late summer, when pasture growth was decreasing and the capacity of selection by the cows was diminished. One explanation for the continued effect on milk production would be a higher peak of lactation for the CLA-treated cows and a resultant increase in persistency. It is interesting to note that the classic relation of $200 \mathrm{~kg}$ of additional milk to each additional $1 \mathrm{~kg}$ of milk in the peak of lactation might be independent from milk composition. The dispersion of the data of milk yield throughout the experimental period is presented in Figure 1. By comparing the slopes of the lines, it was determined that the persistency was not different between treatments $(-0.0693 \pm 0.0025$ vs. $-0.0736 \pm 0.0021)$.

The mean milk fat content was not different between treatments in the residual period (Table 4), but there was a treatment by time interaction, as the values in the first week of the residual period were different between treatments, with values of 3.09 and $2.52 \%$, respectively for control and CLA cows (Figure 2). These results were expected becausee CLA acts to inhibit lipogenic enzymes, and the reduced lipogenesis will last until the normal enzyme abundance is achieved again. Therefore, restoration of normal milk fat synthesis takes a few days to occur. There was no longer a difference between treatments in the second week of the residual period.

Protein content was still higher for CLA-treated cows during the residual period $(P=0.017)$ with a significant interaction of time by treatment: during the first week (wk 9), protein for the CLA treatment was higher (3.16 vs. 2.83). Nevertheless, the values for the final $3 \mathrm{wk}$ of the residual period were not statistically different. This pattern was similar to that of fat content in the same period, which indicates that the increase in protein is an episode dependent of the fat reduction, as pointed out by Perfield et al. (2002). Interestingly, in the present work, there was no indication of change in energy balance due to CLA treatment.

Milk energy density $(\mathrm{MJ} / \mathrm{kg}$ ) was almost identical during the residual period once milk composition, except for protein in the first week, was the same. Net energy output $(\mathrm{MJ} / \mathrm{d})$, as in the treatment period, was not different, but tended to be greater for CLA cows $(P$ $=0.088$ ) as milk fat content was already similar, but production was still greater for CLA-treated cows.

There was a residual effect of CLA supplementation for protein production $(P=0.006)$ as a result of greater
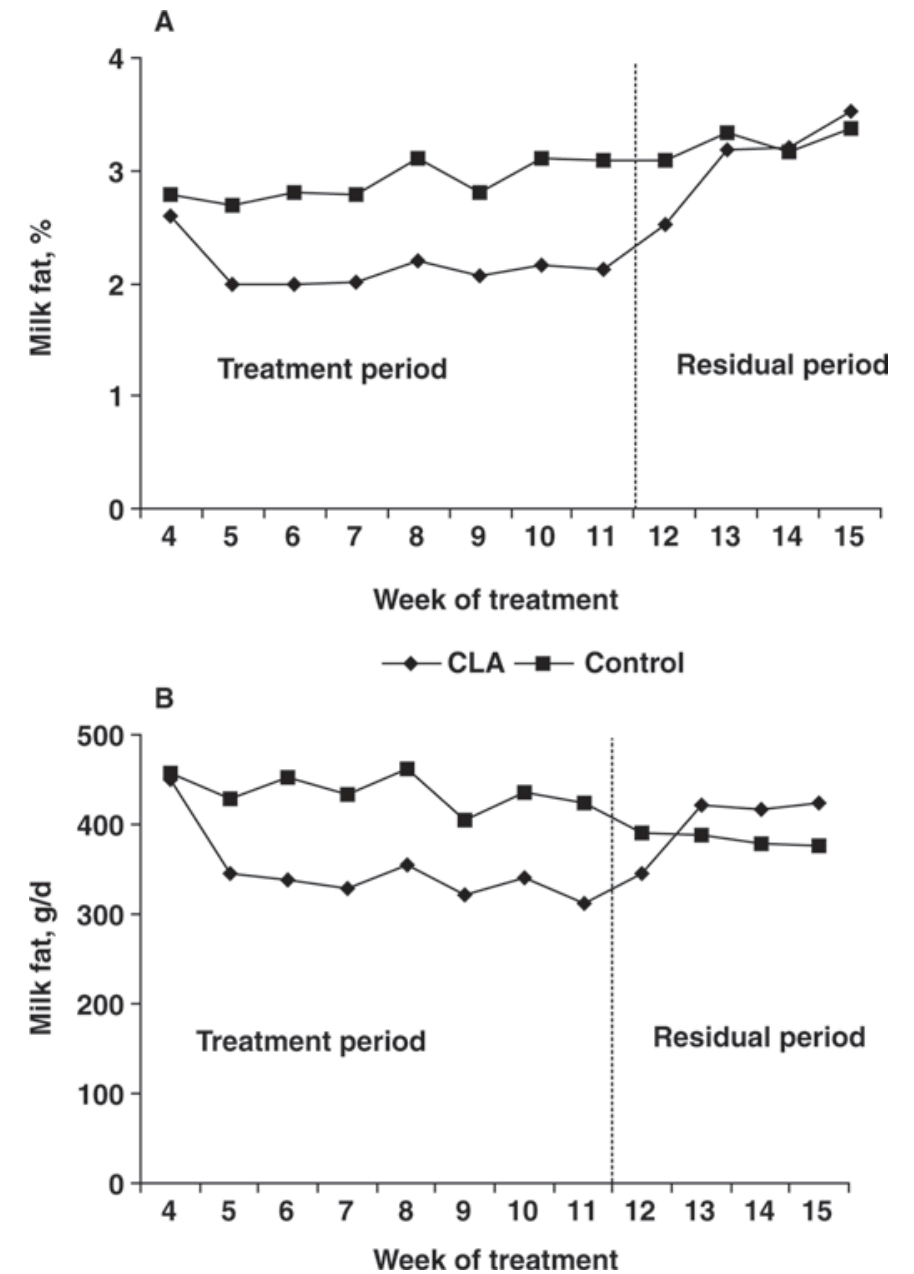

Figure 2. Temporal pattern of milk fat content (A) and milk fat yield (B) for cows fed a rumen-protected fat supplement with (CLA, -) or without conjugated linoleic acid (control, - ) from 28 to $84 \mathrm{~d}$ (treatment period) and a commercial concentrate without CLA from 85 to 112 d (residual period).

protein content and milk volume. This result is mostly because of the greater protein content in the first week of the residual period, which would probably disappear if the investigation of the residual period continued further. In addition, as lactation proceeds, it is easier for the cow to be in a more positive energy balance, theoretically changing the response of the cow to CLA.

There was no effect of CLA supplementation on BW and BCS, and those variables were kept constant throughout the experiment (Tables 3 and 4). The absence of recovery of BCS is consistent with an energy-restricted environment. In fact, the restriction in nutritional resources was already clearly indicated by the increased milk production in response to CLA treatment. Some authors suggest that CLA could inhibit fat synthesis in adipose tissue; however, the CLA concentration required to affect mammary lipogenesis 
Table 5. Fatty acid composition (g/100 g) of milk fat from cows receiving rumen-protected fat supplements from 28 to 84 DIM (treatment period) and without this supplement from 85 to 112 DIM (residual period) ${ }^{1}$

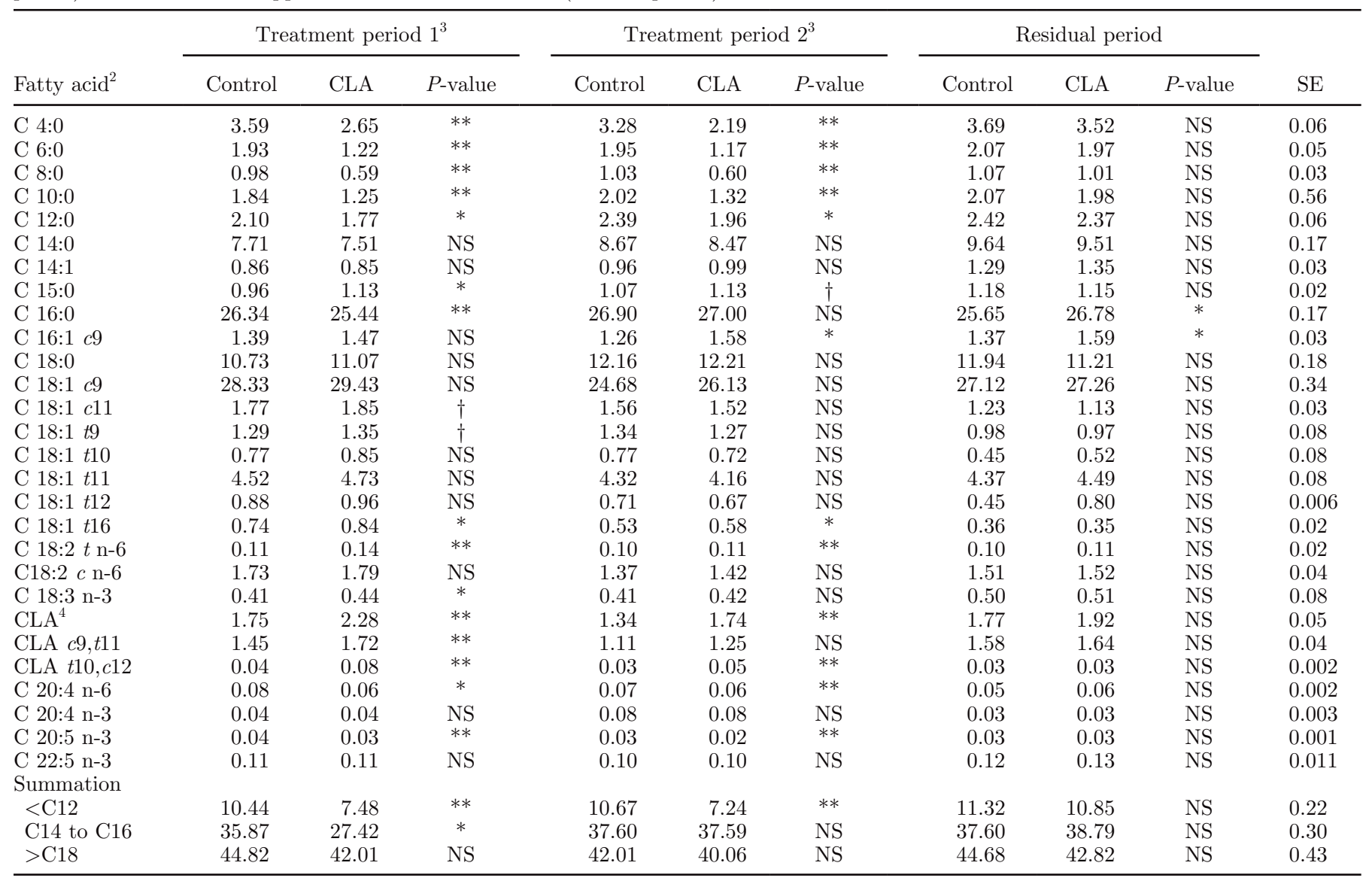

${ }^{1}$ Cows received a supplement consisting of Ca-salts of palm oil fatty acids (control) or Ca-salts of a mixture of conjugated linoleic acid isomers (CLA). Both treatments provided about $105 \mathrm{~g} / \mathrm{d}$ of fatty acids.

${ }^{2} c=$ cis; $t=$ trans.

${ }^{3}$ Treatment period 1: milk collected from d 42 to 47 ; treatment period 2: milk collected from d 70 to 74 .

${ }^{4}$ Sum of cis-9,trans-11, trans-10, cis-12, and other unrecognized fatty acids.

${ }^{*} P<0.05 ;{ }^{* *} P<0.01 ; \dagger P<0.10$.

is much lower than that needed to inhibit lipogenesis in adipose tissue (Bauman et al., 2008).

\section{Milk Fatty Acid Composition and Yield}

Among all fatty acid chain lengths, there was a greater reduction in short-chain fatty acids in milk fat of the CLA-treated group $(P<0.001$; Table 5$)$. This reduction (Table 6) was consistent with the proposed CLA action in lipid metabolism (Bauman and Griinari, 2003; Bauman et al., 2008; Harvatine et al., 2009) because CLA acts on many lipogenic enzymes, like acetylCoA-carboxylase and fatty acid synthase (Piperova et al., 2000; Hayashi et al., 2007), although there are also effects on enzymes involved in long-chain fatty acid metabolism (Bauman et al., 2008).
Palmitic acid (C16:0) concentration for the CLA cows was lower $(P=0.0023)$ in the first period of sampling (42-47 DIM), but not $(P=0.8098)$ in the second one (70-74 DIM; Table 5). As C16:0 in milk can come from dietary fat and tissue mobilization or from de novo synthesis, this suggests a shift in the relative importance of those sources due to lactation stage; that is, de novo synthesis would proportionally decrease its participation as milk yield is less demanding. In the first period of sampling (42-47 DIM), cows were producing 15 to $18 \mathrm{~kg}$ of milk, whereas in the second period (70-74 DIM), cows were producing 13 to $16 \mathrm{~kg}$. Nevertheless, the difference between fatty acids with $<16$ carbons in the first and second periods of sampling was small, with the recovery of C16:0 content occurring by the time of the second sampling. 
Table 6. Yield of fatty acids $(\mathrm{g} / \mathrm{d})$ from cows receiving rumen-protected fat supplements from 28 to 84 DIM (treatment period) and without this supplement from 85 to 112 DIM (residual period) ${ }^{1}$

\begin{tabular}{|c|c|c|c|c|c|c|c|c|c|c|}
\hline \multirow[b]{2}{*}{ Fatty $\operatorname{acid}^{2}$} & \multicolumn{3}{|c|}{ Treatment period $1^{3}$} & \multicolumn{3}{|c|}{ Treatment period $2^{3}$} & \multicolumn{3}{|c|}{ Residual period } & \multirow[b]{2}{*}{$\mathrm{SE}$} \\
\hline & Control & CLA & $P$-value & Control & CLA & $P$-value & Control & CLA & $P$-value & \\
\hline C $6: 0$ & 8.5 & 5.3 & $* *$ & 8.4 & 3.7 & ** & 8.2 & 8.7 & NS & 2.3 \\
\hline C 8:0 & 4.4 & 2.6 & $* *$ & 4.5 & 1.9 & $* *$ & 4.3 & 4.5 & NS & 1.4 \\
\hline C 10:0 & 8.2 & 5.4 & $* *$ & 8.8 & 4.2 & $* *$ & 8.2 & 8.8 & NS & 2.7 \\
\hline C 12:0 & 9.3 & 7.5 & $*$ & 10.4 & 6.4 & $* *$ & 9.6 & 10.5 & NS & 2.8 \\
\hline C 15:0 & 4.1 & 4.8 & $*$ & 4.6 & 3.8 & $\dagger$ & 4.6 & 5.0 & NS & 0.7 \\
\hline C $16: 0$ & 113.5 & 109.9 & $* *$ & 114.6 & 89.9 & $*$ & 101.0 & 116.7 & NS & 15.0 \\
\hline C $16: 1 c 9$ & 6.0 & 6.2 & NS & 5.4 & 5.3 & NS & 5.4 & 6.9 & $\dagger$ & 1.3 \\
\hline C 18:0 & 46.3 & 48.1 & NS & 51.8 & 39.3 & $*$ & 46.6 & 48.6 & NS & 8.4 \\
\hline C $18: 1 c 9$ & 122.5 & 127.6 & NS & 105.2 & 85.7 & $*$ & 105.0 & 118.2 & NS & 16.9 \\
\hline C $18: 1 c 11$ & 7.7 & 8.0 & $\dagger$ & 6.5 & 5.0 & ** & 4.8 & 4.9 & NS & 0.9 \\
\hline C $18: 1$ t9 & 5.6 & 5.9 & $\dagger$ & 5.8 & 4.2 & $* *$ & 3.8 & 4.2 & NS & 2.9 \\
\hline C $18: 2 c n-6$ & 7.4 & 7.8 & NS & 5.8 & 4.7 & $*$ & 6.1 & 6.6 & NS & 1.3 \\
\hline C $18: 3$ n-3 & 1.7 & 1.9 & $*$ & 1.8 & 1.4 & $*$ & 2.0 & 2.2 & NS & 0.4 \\
\hline CLA $^{4}$ & 7.5 & 9.8 & $* *$ & 5.7 & 5.8 & NS & 7.0 & 8.4 & NS & 1.6 \\
\hline CLA $c 9, t 11$ & 6.2 & 7.4 & $* *$ & 4.8 & 4.2 & NS & 6.3 & 7.2 & NS & 1.5 \\
\hline CLA $t 10, c 12$ & 0.2 & 0.3 & $* *$ & 0.1 & 0.1 & $*$ & 0.1 & 0.1 & NS & 0.1 \\
\hline C $20: 4$ n- 6 & 0.3 & 0.3 & $*$ & 0.3 & 0.2 & $* *$ & 0.2 & 0.3 & $\dagger$ & 0.1 \\
\hline C 20:1 & 0.5 & 0.6 & $*$ & 0.9 & 0.7 & NS & 0.8 & 1.0 & NS & 0.4 \\
\hline C $20: 4$ n-3 & 0.2 & 0.2 & NS & 0.4 & 0.2 & $*$ & 0.1 & 0.1 & NS & 0.1 \\
\hline C $20: 5$ n-3 & 0.2 & 0.1 & $* *$ & 0.1 & 0.1 & ** & 0.1 & 0.1 & NS & 0.1 \\
\hline C $22: 6 n-3$ & 0.5 & 0.5 & $* *$ & 0.3 & 0.2 & $*$ & 0.1 & 0.2 & NS & 0.1 \\
\hline
\end{tabular}

${ }^{1}$ Cows received dietary supplement consisting of Ca-salts of palm oil fatty acids (control) or Ca-salts of a mixture of conjugated linoleic acid isomers (CLA). Both treatments provided about $105 \mathrm{~g} / \mathrm{d}$ of fatty acids.

${ }^{2} c=$ cis; $t=$ trans.

${ }^{3}$ Treatment period 1: milk collected from d 42 to 47 ; treatment period 2: milk collected from d 70 to 74 .

${ }^{4}$ Sum of cis-9,trans-11, trans-10, cis-12, and other unrecognized fatty acids.

${ }^{*} P<0.05 ;{ }^{* *} P<0.01 ; \dagger P<0.10$.

The CLA in milk fat originates mainly from endogenous synthesis involving the precursor 18:1 trans-11 and mammary $\Delta^{9}$-desaturase (Bauman and Lock, 2006). The reduction in CLA concentration (Table 5) observed from the first (42-47 DIM) to the second period (70-74 DIM) of milk sampling was possibly related to changes in the biohydrogenation pathway, with reductions in CLA precursors (18:1 trans-11; vaccenic acid). Consistent with that, there was a decrease in 18:1 trans-11 from the first to the second period (4.73 vs. $4.32 \%$ ), and the same occurred for 18:1 trans-10 (0.85 vs. 0.72\%). The opposite occurred with CLA trans-10, cis-12, which increased in the same comparison.

For total CLA yield, the greater concentration in the CLA-supplemented animals (Table 5) was not enough to compensate for the MFD, such that there was no difference in the total CLA yield in the second period (Table 6). However, in the first period, CLA yield was $32 \%$ greater for CLA-treated compared with control cows. The yield of trans-10,cis-12 was higher for CLAtreated cows in both periods, but the difference was lower in the second period $(P<0.05)$ compared with the first $(P<0.001)$. The recovery of trans-10, cis-12 in milk of animals receiving CLA-60 of approximately $0.2 \mathrm{~g} / \mathrm{d}$ represents less than $1 \%$ of estimated trans10 ,cis-12 offered, suggesting that protection was not very effective. This was expected given that CLA-60 is rich in polyunsaturated fatty acids, which are less efficiently protected from biohydrogenation (Sukhija and Palmquist, 1990).

Secretion of cis-9,trans-11 (rumenic acid) was significantly decreased in the milk of CLA-treated animals in the second period of collection compared with the first period. In the second period, there was no difference between the CLA-treated cows and the control cows for rumenic acid yield (Table 6). This finding results from both a smaller difference in content of this isomer and a less pronounced difference in the total fat yield in the 
Table 7. Desaturase index from cows during CLA treatment from 28 to 84 DIM (treatment period) and after CLA treatment from 85 to 112 DIM (residual period) ${ }^{1}$

\begin{tabular}{|c|c|c|c|c|c|c|c|c|c|c|}
\hline Fatty acid & \multicolumn{3}{|c|}{ Treatment period $1^{2}$} & \multicolumn{3}{|c|}{ Treatment period $2^{2}$} & \multicolumn{3}{|c|}{ Residual period } & $\mathrm{SE}$ \\
\hline $\mathrm{C} 14: 1 / \mathrm{C} 14: 0$ & 0.11 & 0.11 & NS & 0.11 & 0.12 & NS & 0.13 & 0.14 & NS & 0.02 \\
\hline $\mathrm{C} 18: 1 / \mathrm{C} 18: 0$ & 3.37 & 3.41 & NS & 2.66 & 2.75 & NS & 2.93 & 3.16 & NS & 0.42 \\
\hline
\end{tabular}

${ }^{1}$ Cows received a dietary fat supplement consisting of Ca-salts of palm oil fatty acids (control) or Ca-salts of a mixture of conjugated linoleic acid isomers (CLA). Both treatments provided about $105 \mathrm{~g} / \mathrm{d}$ of fatty acids.

${ }^{2}$ Treatment period 1: milk collected from d 42 to 47 ; treatment period 2: milk collected from d 70 to 74 .

$* P<0.05$.

second period. This difference may be partly related to changes in the fatty acid profile of the pasture throughout the year, as reported by Auldist et al. (2002).

For fatty acid content in the residual period, there were only minor differences or tendencies $(P<0.10)$ between treatments for C16:1, C18:1 trans-10, and C20:4 n-6 (Table 5). For all other fatty acids, differences ceased after the end of treatment $(P>0.10)$.

Considering both sampling periods and all C18:1 isomers, only C18:1 trans-16 was higher for CLA-supplemented cows within the treatment period (Table 5). The C18:1 cis-9 isomer is the main unsaturated fatty acid in milk and was not affected by treatment during the whole experiment.

The reason for the concentration of several isomers $>18$ carbons being higher for CLA-supplemented cows (Table 5) could be the lower rate of de novo synthesis, which consequently diminished short-chain fatty acids with a proportional increase in long-chain fatty acids, as observed by many researchers (Baumgard et al., 2000; Perfield et al., 2006; Harvatine et al., 2009). It could also be because of fatty acid dissociation and biohydrogenation of the protected fat supplements in the rumen due to the less effective protection of polyunsaturated fatty acid calcium salts mentioned above.

Activity of $\Delta^{9}$-desaturase can be estimated through the relationship between unsaturated products and their saturated precursors (Table 7). The absence of the expected difference between monounsaturated fatty acids because of CLA inhibition of $\Delta^{9}$-desaturase could be explained by the presence of $\mathrm{C} 20: 5$ in the fishmeal oil (Chilliard et al., 2001). This fatty acid, as well as other polyunsaturated fatty acids in fish oil, may inhibit de novo synthesis and $\Delta^{9}$-desaturase, but as indicated by the present results, to a lesser extent than trans-10, cis-12 (Xu et al., 2001). Differences were not significant, except for C16:1/16:0 in collection period 2; however, the effect was in the opposite direction from what would be expected for MFD. Nevertheless, the effect of reduced activity of $\Delta^{9}$-desaturase and MFD are probably overrated, as shown by Perfield et al. (2006) who demonstrated a large reduction in this enzyme caused by trans-10,trans-12 CLA with no decrease in fat yield. Harvatine et al. (2009) noted that there are few biologically active isomers identified that are capable of reducing milk fat (doses of less than $10 \mathrm{~g} / \mathrm{d}$ can decrease fat content by half), and it would be reasonable to accept that additional unidentified biohydrogenation intermediates could also be involved.

A regression between milk fat concentration and trans-10,cis-12 isomer using data from the treatment period shows that the trans-10, cis-12 concentration in milk increased while the milk fat percentage decreased (Figure 3), similarly to studies involving abomasal infusion of trans-10,cis-12 CLA as summarized by de Veth et al. (2004). The values agree with other trials conducted with higher producing cows.

\section{Plasma Metabolites and MUN}

Plasma concentrations of NEFA tended to be greater for the control treatment $(P=0.0991)$ during the treatment period. Concentrations of NEFA (Table 8) were lower than or equal to values normally observed in high-producing animals (Garcia-Bojalil et al., 1998; Knowlton et al., 1998; Putnam and Varga, 1998), but near those obtained by Sutton et al. (1998) with cows of similar production potential to the animals used in the present experiment. The tendency for greater NEFA in control cows $(P=0.099)$ compared with CLA-treated cows suggests greater mobilization of body reserves, consistent with greater long-chain fatty acid secretion (Castañeda-Gutiérrez et al., 2005). A review of studies involving CLA supplements or infusion of trans-10,cis-12 CLA indicates little or no effect on plasma variables (Bauman et al., 2008; Harvatine et al., 2009). The highest values for NEFA were obtained in the second week sampling: 323 versus $228 \mu \mathrm{mol} / \mathrm{L}$ for control and CLA, respectively. Concentrations of NEFA suggest that negative energy balance was not pronounced in either treatment. 
Table 8. Plasma metabolites and MUN of cows receiving rumen-protected fat supplements from 28 to 84 DIM (treatment period) and without this supplement from 85 to 112 DIM (residual period) ${ }^{1}$

\begin{tabular}{|c|c|c|c|c|c|}
\hline \multirow[b]{2}{*}{ Variable } & \multicolumn{2}{|c|}{ Treatment (Trt) } & \multirow[b]{2}{*}{ SEM } & \multicolumn{2}{|c|}{$P$-value } \\
\hline & Control & CLA & & Trt & Trt $\times$ time \\
\hline \multicolumn{6}{|l|}{ Treatment period } \\
\hline NEFA, $\mu \mathrm{mol} / \mathrm{L}$ & 224 & 176 & 11.0 & 0.0991 & 0.6611 \\
\hline Triglyceride, $\mathrm{mg} / \mathrm{dL}$ & 21.8 & 24.3 & 0.83 & 0.1923 & $<0.0001$ \\
\hline MUN, mg/dL & 19.3 & 19.7 & 0.40 & 0.5162 & 0.9225 \\
\hline \multicolumn{6}{|l|}{ Residual period } \\
\hline NEFA, $\mu \mathrm{mol} / \mathrm{L}$ & 148 & 132 & 10.5 & 0.3782 & 0.1703 \\
\hline Triglyceride, $\mathrm{mg} / \mathrm{dL}$ & 19.2 & 27.5 & 0.75 & $<0.0001$ & $<0.0001$ \\
\hline MUN, mg/dL & 17.6 & 18.3 & 0.50 & 0.4365 & 0.9790 \\
\hline
\end{tabular}

${ }^{1}$ Cows received a dietary fat supplement consisting of Ca-salts of palm oil fatty acids (control) or Ca-salts of a mixture of conjugated linoleic acid isomers (CLA). Both treatments provided about $105 \mathrm{~g} / \mathrm{d}$ of fatty acids.

Differences were not observed during the treatment period for blood TG values although the treatment $x$ time interaction was significant $(P<0.0001)$. During the residual period, means were different (19.2 and 27.5 $\mathrm{mg} / \mathrm{dL}$ for control and CLA treatments, respectively; $P<0.001)$.

There were no treatment effects on MUN, plasma cholesterol, or glucose. The high MUN concentrations are in accordance with the level of protein in the diet. Milk protein content measured at the same time as MUN sampling was 3.10 and $2.82 \%$ for CLA and control cows, respectively. This result indicates that the increase could be due to true protein synthesis and not merely by urea translocating from the blood to the milk. Perfield et al. (2002) did not observe any changes in the proportions of different nitrogen and protein fractions in milk from CLA-treated cows.

\section{Reproductive Data}

Reproductive data were collected throughout the trial to the end of lactation. Estrus was detected by visual observation. After the end of the residual period, cows continued to receive the same commercial concentrate,

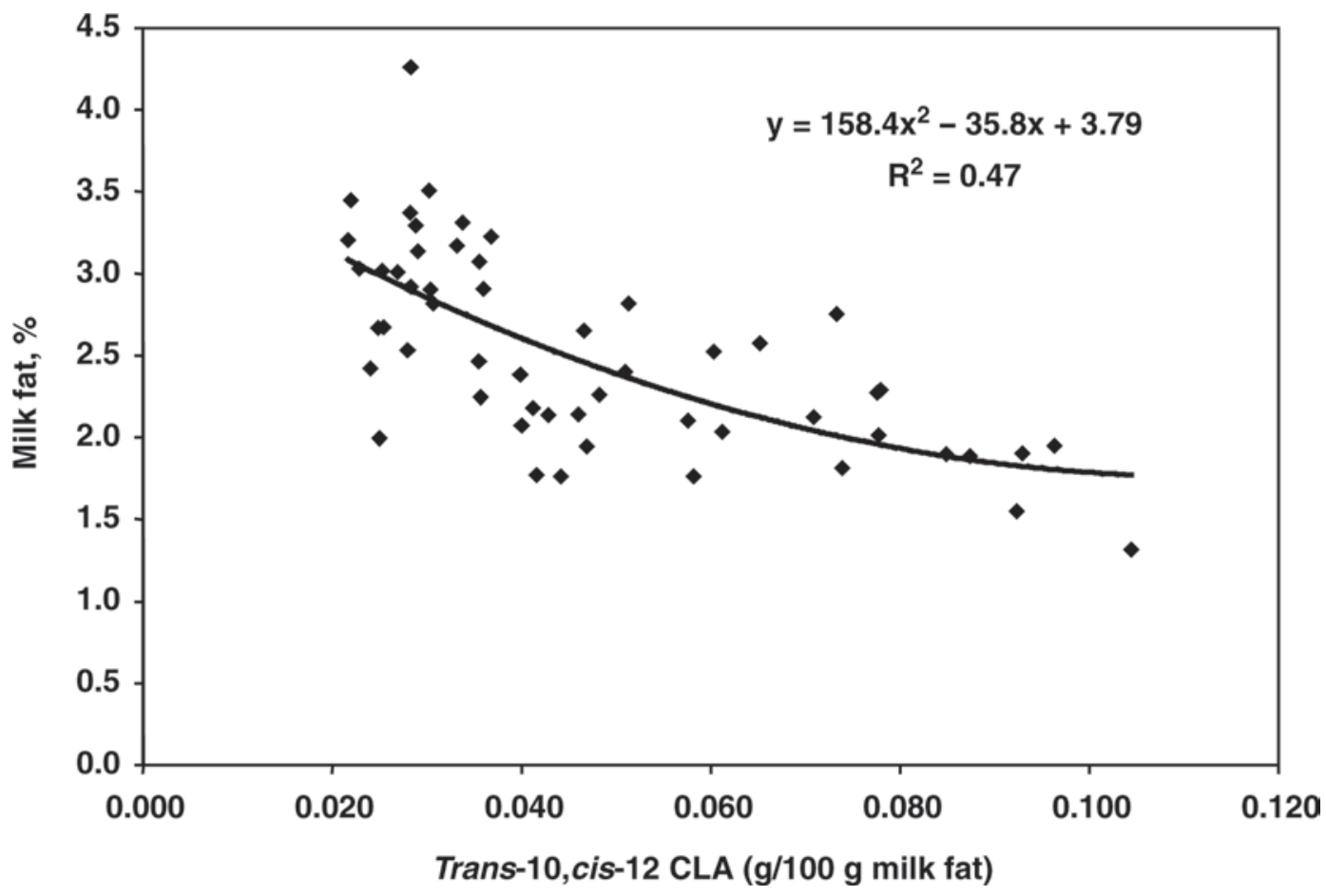

Figure 3. Regression between milk fat percentage and conjugated linoleic acid (CLA) trans-10,cis-12 using data from cows receiving rumenprotected fat supplements from 28 to 84 DIM (treatment period). 
Table 9. Reproductive data of cows receiving rumen-protected fat supplements from 28 to 84 DIM (treatment period) and without this supplement from 85 to 112 DIM (residual period) for over a year after the beginning of the experiment

\begin{tabular}{|c|c|c|c|c|}
\hline \multirow[b]{2}{*}{ Variable } & \multicolumn{2}{|c|}{ Treatment $^{1}$} & \multirow[b]{2}{*}{ SE } & \multirow[b]{2}{*}{$P$-value } \\
\hline & Control & CLA & & \\
\hline Days to first estrus & 111 & 89 & 10 & 0.22 \\
\hline Number of services & 1.95 & 1.45 & 0.34 & 0.36 \\
\hline
\end{tabular}

but the amount given to each cow corresponded to $1 \mathrm{~kg}$ of ration for each $3 \mathrm{~kg}$ of milk above a baseline of $9 \mathrm{~kg}$ of milk. The reproductive data of the cows in the present study (Table 9) are consistent with the challenging environment of the tropical pasture. Although all reproductive variables were favorable to CLA-treated cows, only days open was significantly different $(P=$ $0.08)$. Consistent with our results, a recent meta-analysis of 5 studies involving CLA supplementation in early lactation demonstrated an improvement in reproductive performance (de Veth et al., 2006). Reproductive variables examined included time to first ovulation, time to conception, and overall success of pregnancy. Interestingly, the improvements in reproduction variables were related to the dose of trans-10, cis-12 CLA but not associated with improvements in net energy balance (de Veth et al., 2006). This suggests that CLA effects may be independent of energy balance. In effect, the cows in the present trial did not improve their energy balance because total energy expenditure seemed to be unchanged (i.e., decreased milk energy content was compensated by greater milk volume). Results in vitro and in vivo with certain fat supplements, particularly fish oil and CLA, suggest that the effects on reproduction may be the result of CLA interfering with prostaglandin metabolism (Staples et al., 1998; Mattos et al., 2002).

\section{CONCLUSIONS}

Our results are consistent with the proposed hypothesis that CLA can be used to manipulate milk composition. Supplementation of CLA increased milk yield and protein production in an energy-limited environment. Energy output was unchanged but the relative protein to energy requirements were different in CLA-treated cows. Under these conditions there was an increase in protein content and a decrease in milk fat content. Treatment with CLA also tended to improve reproductive performance.

\section{ACKNOWLEDGMENTS}

The authors acknowledge FAPESP for sponsoring the research project $(98 / 14974-5)$. The support of Elliot Block and Mario Moura (Church and Dwight Inc., Princeton, NJ) is gratefully acknowledged. The assistance of the following colleagues is also appreciated: Maria Antonia Ladalardo Etchegaray [Escola Superior de Agricultura Luiz de Queiroz (ESALQ)], Marco Antonio Sundfeld da Gama (Embrapa Dairy Cattle), Juliano Barbosa (ESALQ), Amanda Aparecida Hayashi (ESALQ), Elaine Patrícia Maltez Souza Francesconi (Centro Universitario Padre Anchieta, Jundiai, Sao Paulo, Brazil), Eduardo Costa Eifert (Embrapa Rice \& Beans, Goiania, Goias, Brazil), Paulo Mazza Rodrigues (FZEA-USP, Pirassununga, Sao Paulo, Brazil), and Fernando Flores Cardoso (Embrapa Pecuária Sul, Embrapa South Animal Husbandry and Sheep, Bage, Rio Grande do Sul, Brazil).

\section{REFERENCES}

AOAC. 2000. Official Methods of Analysis. 17th ed. AOAC, Washington, DC

Auldist, M. J., J. K. Kay, N. A. Thomson, A. R. Napper, and E. S. Kolver. 2002. Concentration of conjugated linoleic acid isomer in milk from cows grazing pasture or fed a mixed ration for an entire lactation. Proc. N.Z. Soc. Anim. Prod. 62:240-241.

Bauman, D. E., and J. M. Griinari. 2003. Nutritional regulation of milk fat synthesis. Annu. Rev. Nutr. 23:203-227.

Bauman, D. E., and A. L. Lock. 2006. Conjugated Linoleic Acid: Biosynthesis And Nutritional Significance. Pages 93-136 in Advanced Dairy Chemistry. P. F. Fox and P. L. H. McSweeney, ed. Springer, New York, NY.

Bauman, D. E., J. W. Perfield II, K. J. Harvatine, and L. H. Baumgard. 2008. Regulation of fat synthesis by conjugated linoleic acid: Lactation and the ruminant model. J. Nutr. 138:403-409.

Baumgard, L. H., B. L. Corl, D. A. Dwyer, A. Saebo, and D. E. Bauman. 2000. Identification of the conjugated linoleic acid isomer that inhibits milk fat synthesis. Am. J. Physiol. 278:179-184.

Bernal-Santos, G., J. W. Perfield, D. M. Barbano, D. E. Bauman, and T. R. Overton. 2003. Production responses of dairy cows to dietary supplementation with conjugated linoleic acid in (CLA) during the transition period and early lactation. J. Dairy Sci. 86:3218-3228.

Castañeda-Gutiérrez, E., T. R. Overton, W. R. Butler, and D. E Bauman. 2005. Dietary supplements of two doses of calcium-salts 
of conjugated linoleic acid during the transition period and early lactation. J. Dairy Sci. 88:1078-1089.

Chilliard, Y., A. Ferlay, and M. Doreau. 2001. Effects of different types of forages, animal fat or marine oils in cows diets on milk fat secretion and composition, especially conjugated: Nutritional control of saturated, polyunsaturated, trans and conjugated linoleic acids (CLA) and polyunsaturated fatty acids. Livest. Prod. Sci. 70:31-48.

Chouinard, P. Y., L. Corneau, D. M. Barbano, L. E. Metzger, and D. E. Bauman. 1999. CLA alter milk fatty acid composition and inhibit fat secretion in dairy cows. J. Nutr. 129:1579-1584.

Christie, W. W. 1982. A simple procedure for rapid transmethylation of glycerolipids and cholesterol esters. J. Lipid Res. 23:10721075.

de Veth, M. J., E. Castañeda-Gutierrez, D. A. Dwyer, A. M. Pfeiffer, D. E. Putnam, and D. E. Bauman. 2006. Response to conjugated linoleic acid in dairy cows differing in energy and protein status. J. Dairy Sci. 89:4620-4631.

de Veth, M. J., J. M. Griinari, A. M. Pfeiffer, and D. E. Bauman. 2004. Effect of CLA on milk fat synthesis in dairy cows: Comparison of inhibition by methyl esters and free fatty acids, and relationships among studies. Lipids 39:365-372.

Gama, M. A. S., P. Garnsworthy, J. M. Griinari, P. R. Leme, P. H. M. Rodrigues, L. M. O. Souza, and D. P. D. Lanna. 2008. Diet-induced milk fat depression: Association with changes in milk fatty acid composition and fluidity of milk fat. Livest. Sci. 115:319-331.

Garcia-Bojalil, C. M., C. R. Staples, C. A. Risco, J. D. Savio, and W. W. Thatcher. 1998. Protein degradability and calcium salts of long chain fatty acids in diets of lactating cows: Productive responses. J. Dairy Sci. 81:1374-1384.

Giesy, J. G., C. H. McGuire, B. Shafii, and T. W. Hanson. 2002 Effect of dose of calcium salts of conjugated linoleic acid (CLA) on percentage and fatty acid content of milk fat in midlactation Holstein cows. J. Dairy Sci. 85:2023-2029.

Hara, A., and N. S. Radin. 1978. Lipid extraction of tissues with lowtoxicity solvent. Anal. Biochem. 90:420-426.

Harvatine, K. J., Y. R. Boisclair, and D. E. Bauman. 2009. Recent advances in the regulation of milk fat synthesis. Animal 3:4054.

Hayashi, A. A., S. R. Medeiros, M. H. Carvalho, and D. P. D. Lanna. 2007. Conjugated linoleic acid (CLA) effects on pups growth, milk composition and lipogenic enzymes in lactating rats. J. Dairy Res. 74:160-166.

Jenness, R. 1985. Biochemical and nutritional aspects of milk and colostrum. Pages 164-197 in Lactation. B. L. Larson, ed. Iowa State Univ. Press, Ames.

Kay, J. K., T. R. Mackle, D. E. Bauman, N. A. Thomson, and L. H. Baumgard. 2007. Effects of a supplement containing trans-10, cis12 conjugated linoleic acid on bioenergetic and milk production parameters in grazing dairy cows fed ad libitum and restricted pasture. J. Dairy Sci. 90:721-730

Kennelly, J. J. 1996. Producing milk with $2.5 \%$ fat-The biology and health implications for dairy cows. Anim. Feed Sci. Technol. 60:161-180.

Knowlton, K. F., T. E. Davison, P. B. Glenn, G. B. Huntington, and R. A. Erdman. 1998. Glucose metabolism and milk yield of cows infused abomasally or ruminally with starch. J. Dairy Sci. $73: 1784-1787$.

Loor, J. J., and J. H. Herbein. 1998. Exogenous conjugated linoleic acid isomers reduce bovine milk fat concentration and yield by inhibiting de novo fatty acid synthesis. J. Nutr. 128:2411-2419.
Mackle, T. R., J. K. Kay, M. J. Auldist, A. K. H. Mcgibbon, B. A. Philpott, L. H. Baumgard, and D. E. Bauman. 2003. Effects of abomasal infusion of conjugated linoleic acid on milk fat concentration and yield from pasture-fed dairy cows. J. Dairy Sci. 86:644-652.

Mattos, R., C. R. Staples, J. Williams, A. Amorocho, M. A. McGuire, and W. W. Thatcher. 2002. Uterine, ovarian and production responses of lactating dairy cows to increase dietary concentrations of Menhaden fishmeal. J. Dairy Sci. 85:755-764.

Moore, C. E., H. C. Hafliger, O. B. Mendivil, S. R. Sanders, D. E. Bauman, and L. H. Baumgard. 2004. Increasing amounts of conjugated linoleic acid progressively reduces milk fat synthesis immediately postpartum. J. Dairy Sci. 87:1886-1895.

Neter, J., M. H. Kutner, C. J. Nachstein, and W. Wasserman. 1996. Applied Linear Statistical Models. 3rd ed. WCB/McGraw-Hill, Boston, MA.

NRC. 1996. Nutrient Requirements of Beef Cattle. 7th rev. ed. National Academy Sci., Washington, DC.

NRC. 2001. Nutrient Requirements of Dairy Cattle. 7th rev. ed. National Academy Sci., Washington, DC.

Oliveira, D. E. 2003. Uso da técnica de n-alcanos para medir o aporte de nutrientes através de estimativas do consumo de forragem em bovines. PhD Thesis. Escola Superior de Agricultura Luiz de Queiroz, Piracicaba, São Paulo, Brazil.

Perfield, J. W. II, G. Bernal-Santos, T. R. Overton, and D. E. Bauman 2002. Effects of dietary supplementation of rumen-protected conjugated linoleic acid in dairy cows during established lactation. J. Dairy Sci. 85:2609-2617.

Perfield, J. W. II, P. Delmonte, A. L. Lock, M. P. Yurawecz, and D. E. Bauman. 2006. Trans-10, trans-12 conjugated linoleic acid does not affect milk fat yield but reduces delta-nine-desaturase index in dairy cows. J. Dairy Sci. 89:2559-2566.

Piperova, L. S., B. B. Beverly, I. Bruckental, J. Sapugna, S. E. Mills, M. P. Yurawecz, J. Fritsche, K. Ku, and R. A. Erdman. 2000 Mammary lipogenic activity, trans fatty acid and conjugated linoleic acids are altered in lactating dairy cows fed a milk fatdepressing diet. J. Nutr. 130:2568-2574.

Putnam, D. E., and G. A. Varga. 1998. Protein density and its influence on metabolite concentration and nitrogen retention by Holstein cows in late gestation. J. Dairy Sci. 81:1608-1618.

SAS Institute. 2000. SAS User's Guide: Statistics. Version 8.2 ed. SAS Institute Inc., Cary, NC.

Staples, C. R., J. M. Burke, and W. W. Thatcher. 1998. Influence of supplemental fats on reproductive tissues and performance of lactating cows. J. Dairy Sci. 81:856-871.

Sukhija, P. S., and D. L. Palmquist. 1990. Dissociation of calcium soaps of long-chain fatty acids in rumen fluid. J. Dairy Sci. $73: 1784-1787$.

Sutton, J. D. 1989. Altering milk composition by feeding. J. Dairy Sci. 72:2801-2814.

Sutton, J. D., I. C. Hart, S. V. Morant, E. S. Schuller, and A. D. Simmonds. 1998. Feeding frequency for lactating cows: Diurnal patterns of hormones and metabolites in peripheral blood in relation to milk-fat concentration. Br. J. Nutr. 60:265-274.

Xu, J., M. Teran-Garcia, J. H. Y. Park, M. T. Nakamura, and S. D. Clarket. 2001. Polyunsaturated fatty acids suppress hepatic sterol regulatory element-binding protein-1 expression by accelerating transcript decay. J. Biol. Chem. 276:9800-9807. 